\title{
Predictors of parenting stress in parents of children diagnosed with autism spectrum disorder: a scoping review
}

\author{
Haytham Mohammad Al-Oran ${ }^{1 *}$ (D) and Lee Khuan²
}

\begin{abstract}
Introduction: Identifying the predictors of parenting stress in parents of children with autism spectrum disorder is crucial to provide the best health-care services.

Main text: The scoping review was conducted. Search engines (EBSCO, Springer, PubMed, Ovid, Google Scholar, and Science Direct) were used to collate published studies between the years 2009 and 2020. Keywords used were parenting stress, parental stress, predictors of parenting stress, Autism disorder, Autism, and scoping review. Primary screening of the titles and abstracts of 1039 articles was conducted. The secondary screening of 348 articles resulted in 27 articles included in this review. The reviewed articles revealed core symptoms of the disorder, namely, behavior problems, and socio-communication impairments strongly linked with the high level of parenting stress.

Conclusion: This scoping review is the initial step toward encouraging future efforts to provide supportive interventions for parents of children with autism spectrum disorder.
\end{abstract}

Keywords: Autism spectrum disorder, Scoping review, Parenting stress, Predictors of parenting stress

\section{Introduction}

Autism spectrum disorder (ASD) is defined as one of the neurodevelopmental disorders with moderate-tosevere difficulties. These difficulties are related to social interaction, communication, and repetitive and restricted behaviors [1]. Besides, ASD is described as a group of disorders that includes autism or autistic disorder, pervasive developmental disorder, and Asperger syndrome. Among these, autism or autistic disorder is currently the most popular form of ASD [1]. Notably, children diagnosed with ASD have difficulties in many aspects of their lives, including social interaction, behavior, communication, and language $[2,3]$. Therefore, it is challenging for children with ASD to manage their behavior, as well as communicate and establish a social relationship with their parents and other people $[4,5]$. In addition, there is no

\footnotetext{
* Correspondence: haytham.oran88@gmail.com

'Department of Pediatric Nursing, Faculty of Nursing, Mutah University,

Al-Karak, Jordan

Full list of author information is available at the end of the article
}

doubt that the main features of ASD are behavioral difficulties and socio-communication skill deficiencies, which contribute to significant stress in parents with these children [6-8].

Invariably, parents are commonly the first to recognize the developmental variations among children with ASD. With that being said, parents who have a child with ASD are more confused and stressed due to unique stressors and demands over time [9-11]. It is observed that the amount of literature on parenting stress is increasing [12, 13]. Everly and Lating [12] defined parenting stress as "a complex construct that involves behavioral, cognitive and affective components, a combination of child and parent characteristics, as well as family situational components as they relate to the person's appraisal on his or her role as a parent" [p. 28]. Furthermore, Rao and Beidel [13] described parenting stress as the strains and pressures experienced when performing care-related tasks for one's child. Thus, parenting stress is a common condition that has

\section{Springer Open}

(- The Author(s). 2021 Open Access This article is licensed under a Creative Commons Attribution 4.0 International License, which permits use, sharing, adaptation, distribution and reproduction in any medium or format, as long as you give appropriate credit to the original author(s) and the source, provide a link to the Creative Commons licence, and indicate if changes were made. The images or other third party material in this article are included in the article's Creative Commons licence, unless indicated otherwise in a credit line to the material. If material is not included in the article's Creative Commons licence and your intended use is not permitted by statutory regulation or exceeds the permitted use, you will need to obtain permission directly from the copyright holder. To view a copy of this licence, visit http://creativecommons.org/licenses/by/4.0/. 
considerable negative impacts on the physical and mental well-being of parents of children with ASD [14, 15]. As far as it is concerned after conducting a thorough search, there is no scoping review about the predictors of parenting stress among parents with children with ASD. Hence, this study is conducted to provide support programs with a comprehensive understanding to parents who may be more vulnerable to developing mental health problems. It is also hoped that these supportive programs could assist parents in coping with their children with ASD and living positively as a family unit. Health-care professionals and nurses working with children with ASD may use this scoping review finding to reduce parenting stress and improve health well-being.

\section{Main text}

Aim

The scoping review is conducted to identify and map the evidence available on the predictive variables correlated with the high level of parenting stress among parents with children with ASD.

\section{Methods}

Various systematic methods available to review published literature were considered and decided. This was performed to ensure that a scoping review of published studies could be conducted as the best way of mapping the trends in predictors of parenting stress research for the last decade. The scoping review approach was especially useful in examining a widely covered area to comprehensively map the literature and identify core concepts, evidence, or published research gaps. Dissimilar to systematic reviews or meta-analyses, scoping reviews did not even narrow the review parameters to clinical trials or require quality assessment. However, this form of the review was rigorous and methodological in its approaches to review the range, extent, and nature of research activity in a specific field. The pioneering work of Arksey and O'Malley [16] was employed in developing our scoping reviews. Arksey and O'Malley [16] stated that the five steps of the scoping review as presented below.

\section{Stage 1: Identifying the research question}

This scoping review attempted to answer the following research question:

What are the predictive factors correlated with the high level of parenting stress among parents with ASD children?

\section{Stage 2: Identifying the relevant studies}

Research papers were searched using the following medical databases: EBSCO, Springer, PubMed, Ovid, and Science Direct. Apart from that, search terms used for review were parenting stress, parental stress, Autism disorder, Autism, Autistic disorder, and scoping review. Databases were also searched with combinations of keyword search terms, medical subject headings, and key subject headings joined together with the Boolean operators "AND" or "OR." Moreover, a search was conducted for literature to identify studies published and focused on the predictive factors associated with a high level of parenting stress in parents with ASD children. Figure 1 PRISMA 2009 diagram shows the flow of literature studies search. First, the initial search found 1201 full-text papers through the search engine results, and an additional seven articles were found from other sources, such as PsycINFO (for psychology-related literature) and ERIC (for education-related literature). Duplication of research papers was removed from the list of those discovered. After that, 1039 papers were screened mainly for the relevant title and abstract articles. The papers' abstracts were then thoroughly read, while 348 papers had been subjected to secondary examination for eligibility after screening. Lastly, the final search for the literature that included 27 papers was conducted.

\section{Stage 3: Determining study selection}

Full-text articles written in English between 2009 and 2020 that examined parenting stress or parental stress as the main study outcome were included. The exclusion criteria were (1) systematic review, (2) articles reviewed, (3) meta-analysis papers, and (4) case reports. The titles and abstracts were read and screened by two authors. The authors independently reviewed the full-text version of the relevant articles. The final decision was determined based on the inclusion and exclusion criteria. Any disagreements were fixed by discussion.

\section{Stage 4: Charting the data}

Methodological characteristics were synthesized from the adapted JBI Template study details, characteristics, and result extraction instrument [17]. The study details charted were citation details, namely, the author or authors, year of publication, country, study aim and design, sample characteristics, and results.

\section{Stage 5: Collating, summarizing, and reporting the data}

Results of the published research on predictive factors of parenting stress in parents with ASD children from 2009 to 2020 are displayed in Table 1.

\section{Discussion}

To the authors' knowledge, no scoping review had investigated the predictive factors correlated with a high level of parenting stress. The evidence suggested that behavioral problems and social-communication impairments 


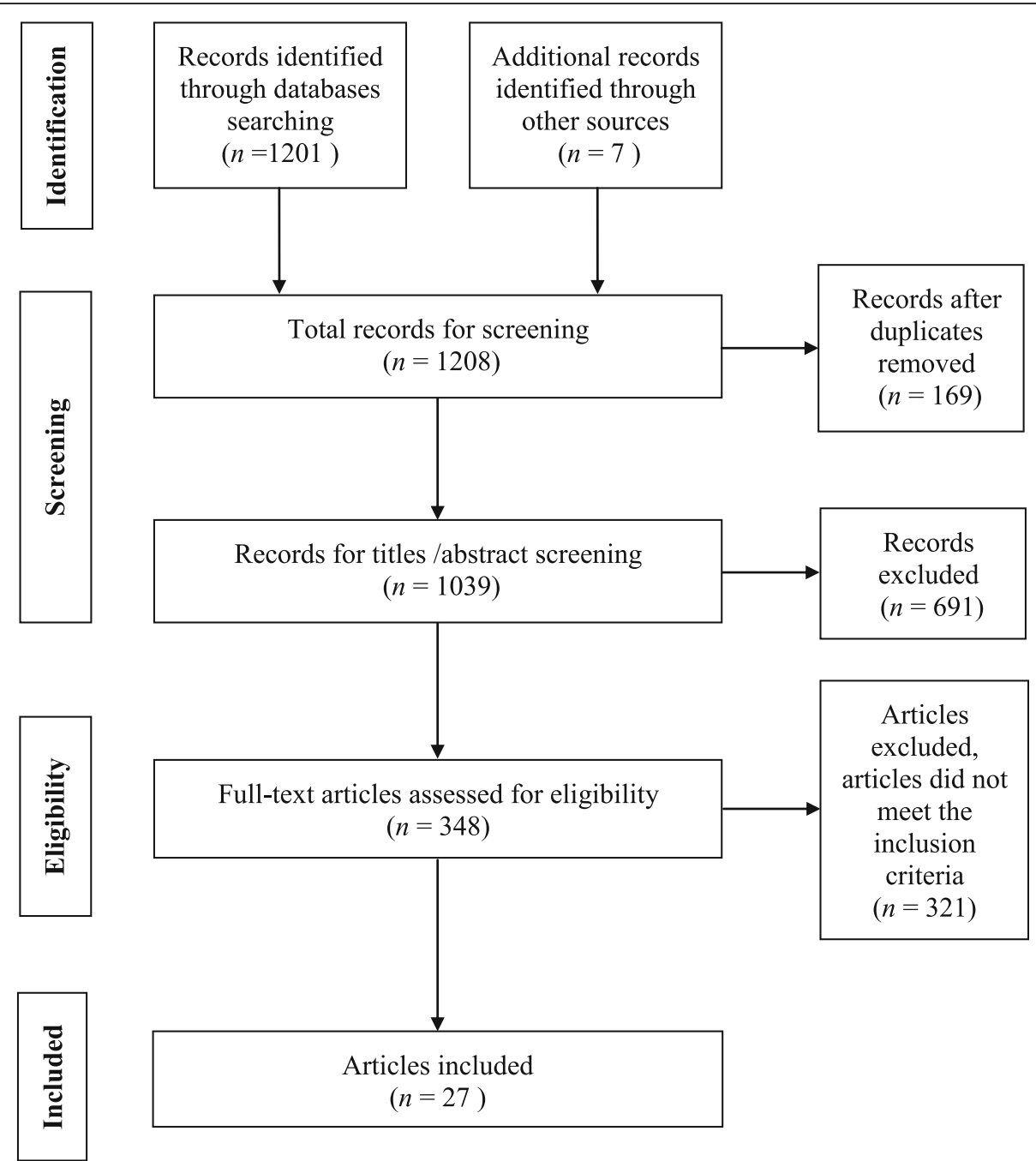

Fig. 1 PRISMA 2009 flowchart for the study selection process

were the two most common predictor factors of the high parenting stress level.

\section{Behavior problems}

As time had passed, more studies related to behavior problems correlated with a high level of parenting stress had been published. The behavior problem was identified in 13 studies as a correlate with high parenting stress $[11,22,23,25,26,28-31,33,35$, 37]. However, there seemed to be contradictory evidence about the significance of the relationship between parenting stress and problem behaviors. For instance, the findings of a study by $\mathrm{Su}$ and colleagues [21] and Peters-Scheffer et al. [38] revealed that the relationship between parenting stress and problem behaviors was not significant. These studies [21, 38] only considered the viewpoints of the mothers and lacked involving the views of the fathers.
Additionally, the small sample size of $\mathrm{Su}$ and colleagues' study [21] and Peters-Scheffer et al.'s study [38] may not have been adequate for the accurate prediction of cross-section study results concerning the association between behavior problems and high level of parenting stress. The small sample sizes may have also affected the findings and led to discrepancies. Additionally, the inclusion of both parents in the study allowed the researcher to identify the predictors of parenting stress of both fathers and mothers systematically that considered its effect on parent's well-being. Hence, to study the whole family structure, it is essential to include both parents and to recruit a larger study sample in future research.

\section{Social-communication impairments}

The scoping review highlighted predictor variables associated with a higher level of parenting stress. In the literature studies, socio-communication impairment was 
Table 1 Summary of published studies on predictors of parenting stress in parents of children with Autism Spectrum Disorder (2009-2020)

\begin{tabular}{lllll}
\hline $\begin{array}{l}\text { Authors/ } \\
\text { year/ } \\
\text { country }\end{array}$ & Study aim & $\begin{array}{l}\text { Study } \\
\text { design }\end{array}$ & Description of study & Predictors addressed Results \\
\hline $\begin{array}{llll}\text { Merdan [18] } \\
\text { Turkey }\end{array}$ & $\begin{array}{l}\text { Identified the correlation } \\
\text { between parenting stress and } \\
\text { children's behavior problem }\end{array}$ & $\begin{array}{l}\text { Cross- } \\
\text { sectional }\end{array}$ & $\begin{array}{l}\text { Sample: one hundred forty- } \\
\text { two mothers of children } \\
\text { with ASD }\end{array}$ & Problem behaviors $\begin{array}{l}\text { Problem behaviors of children } \\
\text { predicted with a high level of } \\
\text { parenting stress }(p=0.001)\end{array}$ \\
\hline
\end{tabular}

$\begin{array}{ll}\text { Pozo and } & \begin{array}{l}\text { Investigated the predictive } \\ \text { association between } \\ \text { Sarriá [19] } \\ \text { Spain }\end{array} \\ & \text { parentiong stress }\end{array}$

Zheng et al. Examined stressors in mothers [20] of preschool- and school-aged Australia children with ASD
Longitudinal Sample: twenty-one study mothers of children with ASD

Instrument:

Parent Stress Index-Short Form (PSI-SF)

Cross- $\quad$ Sample: fifty-six mothers of sectional children with ASD Instrument: Parent Stress

$\begin{array}{ll}\text { Su et al. [21] } & \text { Examined the relationship } \\ \text { China } & \begin{array}{l}\text { between parenting stress and } \\ \text { children's core ASD symptoms }\end{array}\end{array}$

Zaidman-Zait Identified the relations et al. [11] between child behavior Canada problems and parenting stress

Craig et al.

[22]

Italy

Investigated the association of parenting stress with sociodemographic variable, behavioral and emotional problems

Harrop et al. Examined the relationship [23] between child behavior problems and parenting stress

Batool and

Explored the relationship

Khurshid [24] between parent stress and

Pakistan

factors (e.g., social-

communication, parent's gender)

Brei et al.

[25]

USA

Identified the association between parenting stress and autism-associated symptomatology (i.e., problem behaviors, and socialcommunication)

Giovagnoli Investigated the role of several et al. [26] factors in parental stress, Italy sectional Index-Short Form (PSI-SF)

Behavior symptoms A significant relationship between the high level of parenting stress and behavior problem ( $p=0.028$ ) Index-Short Form (PSI-SF)
Crosssectional

s.

Crosssectional

Longitudinal Sample: two hundred study eighty-three mothers of children with ASD Instrument: Parent Stress Index-Short Form (PSI-SF)

Sample: eighty-one parents of children with ASD (father $n=39$, mother $n=42$ ) Instrument: Parent Stress Index-Short Form (PSI-SF)

Longitudinal Sample: one hundred study ninety-three caregivers of children with ASD (biological $n=188$, adoptive $n$ $=3$, maternal grandparent $n=2)$ Instrument: Parent Stress Index-Short Form (PSI-SF)

Cross- Sample: one hundred sectional parents of children with ASD (father $n=50$, mother $n=50$ ) Instrument: Parenting Stress Scale (PSS)

CrossSample: forty parents of children with ASD Instrument: Parent Stress

\section{Cross-} sectional

Sample: one hundred ninety parents of children with ASD (95 fathers, 95mothers) Instrument: Parent Stress

-

twenty-two mothers of children with ASD Instrument: the Depression Anxiety and Stress Scale cognitive ability,

(n)

Behavior problems socialing the impairments of iors, and emotional problems.
Socio-communication impairments, behaviors, and emotional problems
Problem behaviors, communication, daily living skills; socialization and sensory processing

Problem behaviors

Socio-demographic variable (e.g., parent age), behaviors, and emotional problems

Behavior problems

Impairments of socialcommunication and gender of the parent

Repetitive and problematic behaviors $(p=0.05)$, communication and daily living skills $(p=0.05)$, socialization and sensory sensitivities ( $p=$ 0.001 ) were correlated with a high level of parenting stress

No significant correlation between parenting stress and child ASD characteristic ( $p=$ 0.161)

Longitudinal relationship between a high level of parenting stress and behavior problems $(p<0.001)$

Older parents, age of mothers $(p<0.001)$ and age of fathers ( $p=0.021$ ), emotion, and behavior problems ( $p=0.001)$ are predictors of the high level of parenting stress

Longitudinal relationship between behavior problems and a high level of parenting stress $(p<0.001)$

Problem behaviors and socialcommunication skills
Behavioral problems were strongly linked to a high level of parenting stress $(p<0.001)$
The high level of parenting stress strongly associated with behavior and emotional problems $(p<0.001)$$$
\text { problems }(\rho<0.001)
$$

Only socio-communication impairment predictor of a high level of parenting stress $(p<$ 0.001) 
Table 1 Summary of published studies on predictors of parenting stress in parents of children with Autism Spectrum Disorder (2009-2020) (Continued)

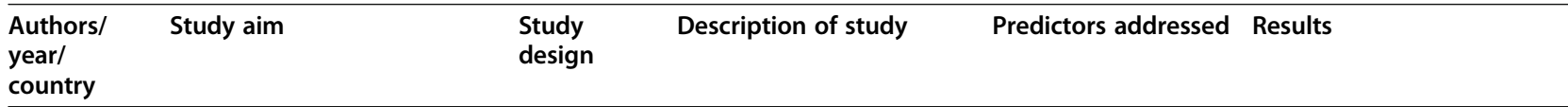

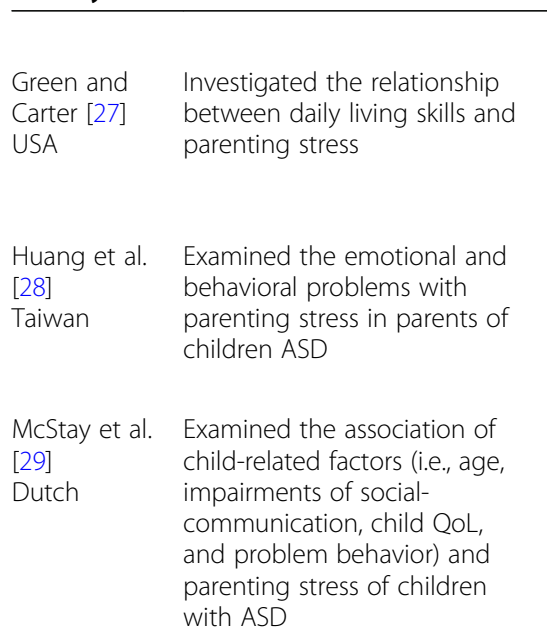

$\begin{array}{ll}\text { Rivard et al. } & \text { Identified the association } \\ \text { [30] } & \text { between ASD core symptoms } \\ \text { Canada } & \text { and parenting stress }\end{array}$

$\begin{array}{ll}\text { Allen et al. } & \text { Examined the association } \\ \text { [31] } & \text { between parenting stress and } \\ \text { Australia } & \text { ASD symptoms }\end{array}$

$\begin{array}{ll}\text { Estes et al. } & \text { Examined child problem } \\ \text { [32] } & \text { behavior, socio- } \\ \text { USA } & \text { communication skills, and daily } \\ & \text { living skills as predictors with } \\ & \text { parenting stress }\end{array}$

Firth and

Dryer [33]

Australia

Totsika et al.

[34]

UK

Walsh et al.

[35]

USA

$\begin{array}{ll}\text { Wang et al. } & \text { Identified factors linked to } \\ \text { [36] } & \text { parenting stress among } \\ \text { China } & \text { mothers of children with ASD }\end{array}$

Weiss et al. Explored the relations between Cross-

[37] child problem behavior and sectional

Crosssectional

Crosssectional

Crosssectional sectional

Crosssectional

Crosssectional
Longitudinal Sample: one hundred sixty- Daily living skills study one mothers of children

with ASD

Instrument: Parent Stress Index-Short Form (PSI-SF)

Sample: fifty-two parents of children with ASD (father $n$

$=8$, mother $n=44$ ) Instrument: Parent Stress Index-Short Form (PSI-SF)

Cross- Sample: one hundred fifty sectional parents of children with ASD (42 fathers, 108 mothers) Instrument: Parent Stress Index-Short Form (PSI-SF)

\section{Sample: two hundred} thirty-six parents of children with ASD (118 fathers and 118 mothers) Instrument: Parent Stress Index-Short Form (PSI-SF)

Sample: one hundred twenty-four parents of children with ASD (23 fathers, 101 mothers) Instrument: Perceived Stress scale (PSS)

Cross- Sample: forty-six mothers of children with ASD Instrument: the

Questionnaire on Resources and Stress (QRS)

Sample: one hundred nine parents of children with ASD

Instrument: the Parental Stress Scale (PSS)

Longitudinal Sample: one hundred study thirty-two mothers of children with ASD Instrument: General Health Questionnaire (GHQ)

Sample: one hundred fortyeight parents of children with ASD (father $n=14$, mother $n=132$ ) Instrument: Parenting Daily Hassles (PDH)

Sample: one hundred fifty mothers of children with ASD Instrument: Parent Stress Index-Short Form (PSI-SF)

Sample: two hundred twenty-eight parents of
Emotional and behavioral problems

of

A significant relationship between the high level of parenting stress and daily living skills $(p=0.05)$

Behavior problems significantly correlated with the high level of parenting stress $(p<0.001)$

Child age, child quality Behavior problems associated of life (Qol), and behavior problems with a high level of parenting stress among parents of children with ASD $(p=0.05)$

Deficits of social-

The high level of parenting communication interaction and behavior problems stress associated with the core ASD $(p<0.001)$

ASD symptoms (social- All ASD symptoms are communication predictors with a high level of interaction, behavior parenting stress $(p=0.05)$ problems)

Child behavior problems and deficits of social-

communication interaction and daily living skills

Problem behaviors and socio-

communication impairments

Behavior problems

Only child behavior problems ( $p=0.006)$ as a significant predictor with a high level of parenting stress

Social impairments $(p<0.001)$ and behavior problems were ( $p$ $<0.001$ ) observed as a predictor of a high level of parenting stress

No significant relationship ( $p=$ 0.321 )

Problem behaviors

Behavior problems were significantly related to a high level of parenting stress ( $p<$ 0.001 )

Behavior problems

Child's behavior problems were correlated with a high level of parenting stress $(p<0.001)$

Child problems behavior
The significant correlation between problem behaviors 
Table 1 Summary of published studies on predictors of parenting stress in parents of children with Autism Spectrum Disorder (2009-2020) (Continued)

\begin{tabular}{|c|c|c|c|c|c|}
\hline $\begin{array}{l}\text { Authors/ } \\
\text { year/ } \\
\text { country }\end{array}$ & Study aim & $\begin{array}{l}\text { Study } \\
\text { design }\end{array}$ & Description of study & Predictors addressed & Results \\
\hline Canada & parenting stress & & $\begin{array}{l}\text { children with ASD (16 fa- } \\
\text { thers and } 212 \text { mothers) } \\
\text { Instrument: Psychological } \\
\text { Distress Scale }\end{array}$ & & $\begin{array}{l}\text { and a high level of parenting } \\
\text { stress }(p<0.001)\end{array}$ \\
\hline $\begin{array}{l}\text { Peters- } \\
\text { Scheffer et al. } \\
\text { [38] } \\
\text { Dutch }\end{array}$ & $\begin{array}{l}\text { Examined factors predicting } \\
\text { parenting stress }\end{array}$ & $\begin{array}{l}\text { Cross- } \\
\text { sectional }\end{array}$ & $\begin{array}{l}\text { Sample: one hundred four } \\
\text { mothers of children with } \\
\text { ASD } \\
\text { Instrument: Parent Stress } \\
\text { Index-Short Form (PSI-SF) }\end{array}$ & $\begin{array}{l}\text { Deficits of social- } \\
\text { communication and } \\
\text { behavior problems }\end{array}$ & $\begin{array}{l}\text { No significant correlation of } \\
\text { social-communication impair- } \\
\text { ments ( } p=0.42) \text {, behavior prob- } \\
\text { lems ( } p=0.21) \text {, and parenting } \\
\text { stress }\end{array}$ \\
\hline $\begin{array}{l}\text { Hall and } \\
\text { Graff [39] } \\
\text { USA }\end{array}$ & $\begin{array}{l}\text { Examined factors associated } \\
\text { with parenting stress }\end{array}$ & $\begin{array}{l}\text { Cross- } \\
\text { sectional }\end{array}$ & $\begin{array}{l}\text { Sample: seventy-five par- } \\
\text { ents of children with ASD } \\
\text { (father } n=25 \text {, mother } n= \\
50 \text { ) } \\
\text { Instrument: Parent Stress } \\
\text { Index-Short Form (PSI-SF) }\end{array}$ & $\begin{array}{l}\text { Deficits of social- } \\
\text { communication inter- } \\
\text { action and daily living } \\
\text { skills }\end{array}$ & $\begin{array}{l}\text { A high level of parenting stress } \\
\text { associated with impairments of } \\
\text { social-communication inter- } \\
\text { action ( } p=0.05) \text { and daily liv- } \\
\text { ing skills ( } p=0.05)\end{array}$ \\
\hline $\begin{array}{l}\text { Rezendes } \\
\text { and Scarpa } \\
{[40]} \\
\text { USA }\end{array}$ & $\begin{array}{l}\text { Assessed parenting stress as } \\
\text { related to behavior problems } \\
\text { in children with ASD }\end{array}$ & $\begin{array}{l}\text { Cross- } \\
\text { sectional }\end{array}$ & $\begin{array}{l}\text { Sample: one hundred forty } \\
\text { mothers of children with } \\
\text { ASD } \\
\text { Instrument: Depression } \\
\text { Anxiety Stress Scale }\end{array}$ & $\begin{array}{l}\text { Child behavior } \\
\text { problems }\end{array}$ & $\begin{array}{l}\text { The high level of parenting } \\
\text { stress among mothers of } \\
\text { children with ASD associated } \\
\text { with behavior problems ( } p< \\
0.001 \text { ) }\end{array}$ \\
\hline $\begin{array}{l}\text { Totsika et al. } \\
{[41]} \\
\text { UK }\end{array}$ & $\begin{array}{l}\text { Investigated the association of } \\
\text { behavioral problems of } \\
\text { children with ASD and } \\
\text { parenting stress }\end{array}$ & $\begin{array}{l}\text { Cross- } \\
\text { sectional }\end{array}$ & $\begin{array}{l}\text { Sample: forty-seven } \\
\text { mothers of children with } \\
\text { ASD } \\
\text { Instrument: maternal well- } \\
\text { being }\end{array}$ & $\begin{array}{l}\text { Child behavior } \\
\text { problems }\end{array}$ & $\begin{array}{l}\text { A significant relationship } \\
\text { between problem behaviors } \\
\text { and the high level of parenting } \\
\text { stress }(p<0.001)\end{array}$ \\
\hline $\begin{array}{l}\text { Osborne and } \\
\text { Reed [42] } \\
\text { UK }\end{array}$ & $\begin{array}{l}\text { Examined the relationship } \\
\text { between characteristics of a } \\
\text { child with ASD and parenting } \\
\text { stress }\end{array}$ & $\begin{array}{l}\text { Cross- } \\
\text { sectional }\end{array}$ & $\begin{array}{l}\text { Sample: one hundred } \\
\text { thirty-seven parents of chil- } \\
\text { dren with ASD } \\
\text { Instrument: Questionnaire } \\
\text { on Resources and Stress } \\
\text { (QRS-F) }\end{array}$ & $\begin{array}{l}\text { Behavior problems, } \\
\text { deficits of social- } \\
\text { communication inter- } \\
\text { action and intellectual } \\
\text { functioning }\end{array}$ & $\begin{array}{l}\text { A high level of parenting stress } \\
\text { was strongly correlated with } \\
\text { child's behavior problems }(p< \\
0.001)\end{array}$ \\
\hline $\begin{array}{l}\text { Phetrasuwan } \\
\text { and Shandor } \\
\text { Miles [43] } \\
\text { USA }\end{array}$ & $\begin{array}{l}\text { Described the factors of } \\
\text { parenting stress in mothers of } \\
\text { children with ASD }\end{array}$ & $\begin{array}{l}\text { Descriptive- } \\
\text { correlational }\end{array}$ & $\begin{array}{l}\text { Sample: one hundred eight } \\
\text { mothers of children with } \\
\text { ASD } \\
\text { Instrument: Parental } \\
\text { Stressor Scale: } \\
\text { Developmental Disabilities } \\
\text { (PSS:DD) }\end{array}$ & Behavior symptoms & $\begin{array}{l}\text { Behavioral problems were } \\
\text { predictors with a high level of } \\
\text { parenting stress ( } p<0.001)\end{array}$ \\
\hline
\end{tabular}

another identified correlation with some contradictory evidence concerning its association with a high level of parenting stress. Seven studies [20, 24, 27, 30, 31, 33, 39] reported that socio-communication impairment is associated with a high level of parenting stress. However, there appears to be some contradictory evidence concerning the significance of the relationship between a high level of parenting stress and impairments in socialcommunication skills $[25,26,32,34,38,42]$.

The small sample size of previous literature studies $[25,26,32,34,38,42]$ was one of the most commonly reported challenges, making it insufficient for the precise estimation results in cross-sectional studies. As a result, the small sample size was a contributing cause for the variation in the association between high levels of parenting stress and impaired socio-communication skills. Apart from that, the population study sample difference was a potential reason for the variation in the correlation between parenting stress and impairments of sociocommunication skills. The findings of a study by Giovagnoli et al. [26] demonstrated that there was no significant association between a high level of parenting stress and impairments of socio-communication skills. In Giovagnoli et al.'s study, the population sample encompassed only mothers with ASD children and male children with ASD. Given the participant's different characteristics, they may show different results representing their various demands. Consequently, it seemed that this participant's profiles might be the cause of contradicting findings. This was because the absence of both parents' gender was limited to identify the correction between parenting stress and socio-communication skills impairments. To conclude, the small sample size may not have been appropriate to accurately determine the 
cross-sectional study results concerning parenting stress and impaired socio-communication skills. Therefore, further research using larger samples, including both parents who have children with ASD, should be implemented.

\section{Strengths and limitations}

This was the first scoping review to describe and identify the breadth of evidence of predictive factors and a high level of parenting stress in parents who have children with ASD. It was noted that the methodology, such as the broad criteria for inclusion and a search strategy, had facilitated the comprehensive identification of studies. The scoping review was also conducted meticulously and robustly. For example, two reviewers independently performed every stage of the screening, selection, and evaluation of the included papers' eligibility. Besides that, theoretical frameworks [16] were used to evaluate the data supporting the results by conducting different scoping analysis stages, including identifying the research question, identifying relevant studies, determining the study selection, charting the data, and collating, summarizing, and reporting the results. Notwithstanding several strengths, there were limitations worthy of note in this scoping review. First, only articles published in English were included. This may cause some articles related to this review not to be captured. Second, most of the studies were conducted in Western countries, so the findings were skewed toward this specific culture. Finally, a formal quality assessment was not undertaken for most identified papers.

\section{Conclusion}

Parenting stress in children with ASD has gained growing attention recently. The current scoping review provides a holistic view concerning the main predictive factors correlated with a high level of parenting stress and offers a good starting point for developing support programs for parenting. Based on the scoping review, there have been consistencies regarding the predictor variables. Previous studies have provided a consistent picture to agree on core ASD symptoms as correlating with a high level of parenting stress. As a result, this scoping review makes a significant contribution to research as a key to the development of an interventional support program that focused mainly on ASD core symptoms. The findings may also make a crucial contribution in helping parents improve their adaptation to stressful situations.

\section{Abbreviations}

ASD: Autism spectrum disorder; PsycINFO: For psychology-related literature; ERIC: Education-related literature; JBI: Joanna Briggs Institute

\section{Acknowledgements}

The authors thank the editorial team and anonymous reviewers for their insightful comments and suggestions.

\section{Authors' contributions}

HMA contributed to the conception, design of the work, and data acquisition; drafted the work, and approved the submitted version. LK contributed to drafting the work, critically revised the manuscript, and approved the submitted version. The authors read and approved the final manuscript.

\section{Funding}

No funding was provided for this review.

\section{Availability of data and materials}

The datasets used during the current scoping review are available from the corresponding author and are ready to be shared upon reasonable request.

\section{Declarations}

Ethics approval and consent to participate

Not applicable.

\section{Consent for publication}

Not applicable.

\section{Competing interests}

The authors declare that they have no competing interests.

\section{Author details}

'Department of Pediatric Nursing, Faculty of Nursing, Mutah University, Al-Karak, Jordan. 'Department of Nursing and Rehabilitation, Faculty of Medicine and Health Science, Universiti Putra Malaysia, Serdang, Selangor, Malaysia.

Received: 1 December 2020 Accepted: 22 June 2021

Published online: 27 July 2021

\section{References}

1. American Psychiatric Association. Diagnostic and statistical manual of mental disorders-5th Edition [DSM-5 ${ }^{\oplus}$. American Psychiatric Pub; 2013.

2. Bluth K, Roberson PN, Billen RM, Sams JM. A stress model for couples parenting children with autism spectrum disorders and the introduction of a mindfulness intervention. J Fam Theory Rev. 2013;5(3):194-213. https://doi. org/10.1111/jftr.12015.

3. Maskey M, Warnell F, Parr JR, Le Couteur A, McConachie H. Emotional and behavioural problems in children with autism spectrum disorder. J Autism Dev Disord. 2013;43(4):851-9. https://doi.org/10.1007/s10803-012-1622-9.

4. Al-Khalaf A, Dempsey I, Dally K. The effect of an education program for mothers of children with autism spectrum disorder in Jordan. Int J Adv Couns. 2014;36(2):175-87. https://doi.org/10.1007/s10447-013-9199-3.

5. Onyemaechi MO, Anyanwu Jl, Onuigbo LN, Ifelunni CO, Alabi-Oparaocha FC, Okenyi EC, Agu MA, Ugwuanyi LT, Ugwuanyi C, Eseadi C, Awoke NN. Rational emotive family health therapy for reducing parenting stress in families of children with autism spectrum disorders: a group randomized control study. J Ration Emot Cogn Behav Ther. 2020;38(2):243-71.

6. Miranda A, Mira A, Berenguer C, Rosello B, Baixauli I. Parenting stress in mothers of children with autism without intellectual disability. Mediation of behavioral problems and coping strategies. Front Psychol. 2019;10:464.

7. Shepherd D, Landon J, Taylor S, Goedeke S. Coping and care-related stress in parents of a child with autism spectrum disorder. Anxiety Stress Coping. 2018;31(3):277-90. https://doi.org/10.1080/10615806.2018.1442614.

8. $\operatorname{Sim}$ A, Cordier R, Vaz S, Netto J, Falkmer T. Factors associated with negative co-parenting experiences in families of a child with autism spectrum disorder. Dev Neurorehabil. 2017;20(2):83-91.

9. Keenan BM, Newman LK, Gray KM, Rinehart NJ. Parents of children with ASD experience more psychological distress, parenting stress, and attachment-related anxiety. J Autism Dev Disord. 2016;46(9):2979-91. https://doi.org/10.1007/s10803-016-2836-Z.

10. Manan Al, Amit N, Said Z, Ahmad M. The influences of parenting stress children behavioral problems and children quality of life on depression 
symptoms among parents of children with autism: preliminary findings. MALAYS J Health Sci. 2018;16:137-43.

11. Zaidman-Zait A, Mirenda P, Duku E, Vaillancourt T, Smith IM, Szatmari P, et al. Impact of personal and social resources on parenting stress in mothers of children with autism spectrum disorder. Autism. 2017;21(2):15566. https://doi.org/10.1177/1362361316633033

12. Everly GS Jr, Lating J. A personality-guided approach to the treatment of posttraumatic stress disorder. Washington, DC: American Psychological Association; 2002.

13. Rao PA, Beidel DC. The impact of children with high-functioning autism on parental stress, sibling adjustment, and family functioning. Behav Modif. 2009;33(4):437-51. https://doi.org/10.1177/0145445509336427.

14. Kakkar J, Srivastava P. Challenges and coping among parents having children with autism spectrum disorder. J Psychosoc Res. 2017;12(2):363-71.

15. Kausar N, Akram B, Dawood S, Ahmad F. Development of an indigenous parental perceived stress scale for children with autism spectrum disorder. Pak J Psychol Res. 2018;34(2):433-56.

16. Arksey H, O'Malley L. Scoping studies: towards a methodological framework. Int J Soc Res Methodol. 2005;8(1):19-32. https://doi.org/10.1080/1364557032 000119616.

17. JBI Reviewer's Manual. Data extraction. https://wiki.joannabriggs.org/display/ MANUAL/11.2.7+Data+extraction. [cited 2020 May 20].

18. Merdan ED. The predictors of parental stress and family resilience in mothers of children with autism spectrum disorder [Doctoral dissertation, İstanbul Bilgi Üniversitesi]; 2019.

19. Pozo P, Sarriá E. Prediction of stress in mothers of children with autism spectrum disorders. Span J Psychol. 2014;17:E6. https://doi.org/10.1017/sjp.2014.6.

20. Zheng $L$, Grove R, Eapen V. Predictors of maternal stress in pre-school and school-aged children with autism. Int J Dev Disabil. 2019;44(2):202-11. https://doi.org/10.3109/13668250.2017.1374931.

21. Su X, Cai RY, Uljarević M. Predictors of mental health in Chinese parents of children with autism spectrum disorder [ASD]. J Autism Dev Disord. 2018; 48(4):1159-68. https://doi.org/10.1016/j.psychres.2016.05.016.

22. Craig F, Operto FF, De Giacomo A, Margari L, Frolli A, Conson M, Ivagnes S, Monaco M, Margari F. Parenting stress among parents of children with neurodevelopmental disorders. Psychiatry Res. 2016;242:121-9. https://doi. org/10.1016/j.psychres.2016.05.016.

23. Harrop C, McBee M, Boyd BA. How are child restricted and repetitive behaviors associated with caregiver stress over time? A parallel process multilevel growth model. J Autism Dev Disord. 2016;46(5):1773-83. https:// doi.org/10.1007/s10803-016-2707-7.

24. Batool SS, Khurshid S. Factors associated with stress among parents of children with autism. J Coll Physicians Surg Pak. 2015;25(10):752-6. https:// doi.org/10.2015/JCPSP.752756.

25. Brei NG, Schwarz GN, Klein-Tasman BP. Predictors of parenting stress in children referred for an autism spectrum disorder diagnostic evaluation. J Dev Phys Disabil. 2015;27(5):617-35. https://doi.org/10.1007/s10882-01 5-9439-z.

26. Giovagnoli G, Postorino V, Fatta LM, Sanges V, De Peppo L, Vassena L, De Rose P, Vicari S, Mazzone L. Behavioral and emotional profile and parental stress in preschool children with autism spectrum disorder. Res Dev Disabil. 2015;45:411-21.

27. Green SA, Carter AS. Predictors and course of daily living skills development in toddlers with autism spectrum disorders. J Autism Dev Disord. 2014;44(2): 256-63. https://doi.org/10.1007/s10803-011-1275-0

28. Huang CY, Yen HC, Tseng MH, Tung LC, Chen YD, Chen KL. Impacts of autistic behaviors, emotional and behavioral problems on parenting stress in caregivers of children with autism. J Autism Dev Disord. 2014;44(6):138390. https://doi.org/10.1007/s10803-013-2000-y.

29. McStay RL, Dissanayake C, Scheeren A, Koot HM, Begeer S. Parenting stress and autism: the role of age, autism severity, quality of life and problem behaviour of children and adolescents with autism. Autism. 2014;18(5):50210. https://doi.org/10.1177/1362361313485163.

30. Rivard M, Terroux A, Parent-Boursier C, Mercier C. Determinants of stress in parents of children with autism spectrum disorders. J Autism Dev Disord. 2014;44(7):1609-20. https://doi.org/10.1007/s10803-013-2028-z.

31. Allen KA, Bowles TV, Weber LL. Mothers' and fathers' stress associated with parenting a child with autism spectrum disorder. Autism Insights. 2013:5.

32. Estes A, Olson E, Sullivan K, Greenson J, Winter J, Dawson G, Munson J. Parenting-related stress and psychological distress in mothers of toddlers with autism spectrum disorders. Brain Dev. 2013;35(2):133-8. https://doi. org/10.1016/j.braindev.2012.10.004

33. Firth I, Dryer R. The predictors of distress in parents of children with autism spectrum disorder. Int J Dev Disabil. 2013;38(2):163-71. https://doi.org/10.31 09/13668250.2013.773964.

34. Totsika V, Hastings RP, Emerson E, Lancaster GA, Berridge DM, Vagenas D. Is there a bidirectional relationship between maternal wellbeing and child behavior problems in autism spectrum disorders? Longitudinal analysis of a population defined sample of young children. Autism Res. 2013;6(3):201-11. https://doi.org/10.1002/aur.1279.

35. Walsh CE, Mulder E, Tudor ME. Predictors of parent stress in a sample of children with ASD: pain, problem behavior, and parental coping. Res Autism Spectr Disord. 2013;7(2):256-64. https://doi.org/10.1016/.j.rasd.2012.08.010.

36. Wang J, Hu Y, Wang Y, Qin X, Xia W, Sun C, Wu L, Wang J. Parenting stress in Chinese mothers of children with autism spectrum disorders. Soc Psychiatry Psychiatr Epidemiol. 2013;48(4):575-82. https://doi.org/10.1007/ s00127-012-0569-7.

37. Weiss JA, Cappadocia MC, MacMullin JA, Viecili M, Lunsky Y. The impact of child problem behaviors of children with ASD on parent mental health: the mediating role of acceptance and empowerment. Autism. 2012;16(3):26174. https://doi.org/10.1177/1362361311422708.

38. Peters-Scheffer N, Didden R, Korzilius H. Maternal stress predicted by characteristics of children with autism spectrum disorder and intellectual disability. Res Autism Spectr Disord. 2012;6(2):696-706. https://doi.org/10.101 6/j.rasd.2011.10.003.

39. Hall HR, Graff JC. The relationships among adaptive behaviors of children with autism, family support, parenting stress, and coping. Issues Compr Pediatr Nurs. 2011;34(1):4-25. https://doi.org/10.3109/01460862.2011.555270.

40. Rezendes DL, Scarpa A. Associations between parental anxiety/depression and child behavior problems related to autism spectrum disorders: the roles of parenting stress and parenting self-efficacy. Autism Res Treat. 2011;2011: 1-10. https://doi.org/10.1155/2011/395190.

41. Totsika V, Hastings RP, Emerson E, Lancaster GA, Berridge DM. A population based investigation of behavioural and emotional problems and maternal mental health: associations with autism spectrum disorder and intellectual disability. J Child Psychol Psychiatry. 2011;52(1):91-9. https://doi.org/10.1111/ j.1469-7610.2010.02295.x

42. Osborne $L A$, Reed $P$. The relationship between parenting stress and behavior problems of children with autistic spectrum disorders. Except Child. 2009;76(1):54-73. https://doi.org/10.1177/001440290907600103.

43. Phetrasuwan S, Shandor Miles M. Parenting stress in mothers of children with autism spectrum disorders. J Spec Pediatr Nurs. 2009;14(3):157-65. https://doi.org/10.1111/j.1744-6155.2009.00188.x.

\section{Publisher's Note}

Springer Nature remains neutral with regard to jurisdictional claims in published maps and institutional affiliations.

\section{Submit your manuscript to a SpringerOpen ${ }^{\circ}$ journal and benefit from:}

- Convenient online submission

- Rigorous peer review

- Open access: articles freely available online

- High visibility within the field

- Retaining the copyright to your article

Submit your next manuscript at $\boldsymbol{\nabla}$ springeropen.com 